\title{
Synthesis, Structures, and Antibacterial Activities of Hydrazone Compounds Derived from 4-Dimethylaminobenzohydrazide
}

\author{
Guo-Xu He and Ling-Wei Xue \\ School of Chemical and Environmental Engineering, Pingdingshan University, Pingdingshan Henan 467000, P. R. China \\ *Corresponding author: E-mail: pdsuchemistry@163.com
}

Received: 08-13-2020

\begin{abstract}
A series of three new hydrazone compounds derived from the condensation reactions of 4-dimethylaminobenzohydrazide with 4-dimethylaminobenzaldehyde, 2-chloro-5-nitrobenzaldehyde and 3-methoxybenzaldehyde, respectively, were prepared. The compounds were characterized by elemental analysis, infrared and UV-vis spectra, HRMS, ${ }^{1} \mathrm{H}$ NMR and ${ }^{13} \mathrm{C}$ NMR spectra, and single crystal X-ray diffraction. Crystals of the compounds are stabilized by hydrogen bonds. The compounds were assayed for antibacterial (Bacillus subtilis, Escherichia coli, Pseudomonas fluorescence and Staphylococcus aureus) and antifungal (Aspergillus niger and Candida albicans) activities by MTT method. The results indicated that compound $\mathbf{2}$ is an effective antibacterial material.
\end{abstract}

Keywords: Hydrazone compound; crystal structure; hydrogen bonds; X-ray crystallography; antimicrobial activity

\section{Introduction}

Hydrazone compounds have been reported to possess interesting biological activities. Some of the compounds are found to be useful for the treatment of inflammatory diseases and tumors, ${ }^{1}$ and some of the compounds have antibacterial, antifungal, antiviral, and many other activities. ${ }^{2}$ The emphasis on structural studies of hydrazone compounds is a consequence of our interests in compounds having potential biological activity. In addition, hydrazone compounds have also been used as preferred ligands in construction of versatile structures of complexes with various metal salts like manganese, copper, vanadium and zinc. ${ }^{3}$ The complexes displayed interesting biological and catalytic activities. It was reported that the compounds bearing one or more halo-substituents on the aromatic ring have improved biological activities, es- pecially for the antibacterial and antifungal activities. ${ }^{4} \mathrm{How}$ ever, the structure-activity relationship was not clear until now. As an extension of our work on the structures and antibacterial activities of such compounds, in the present paper, three new hydrazone compounds, $N$-(4-dimethylaminobenzylidene)-4-dimethylaminobenzohydrazide (1), $N^{\prime}$-(2chloro-5-nitrobenzylidene)-4-dimethylaminobenzohydrazide (2), and $N^{\prime}$-(3-methoxybenzylidene)-4-dimethylaminobenzohydrazide (3) (Scheme 1), are reported.

\section{Experimental}

\section{1. Materials and Methods}

4-Dimethylaminobenzohydrazide, 4-dimethylaminobenzaldehyde, 2-chloro-5-nitrobenzaldehyde and

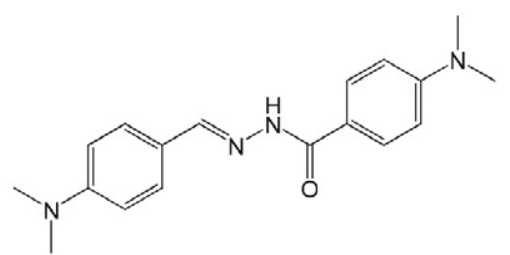

1<smiles>CN(C)c1ccc(C(=O)N/N=C/c2cc([N+](=O)[O-])ccc2Cl)cc1</smiles>

2<smiles>COc1cccc(/C=N/NC(=O)c2ccc(N(C)C)cc2)c1</smiles>

3

Scheme 1. The hydrazone compounds. 
3-methoxybenzaldehyde with AR grade were purchased from Fluka and used as received. All other chemicals with AR grade were obtained commercially and used without purification. Elemental analyses were carried out on a Perkin-Elmer model 240 analyzer. HRMS data was obtained with ESI (electrospray ionization) mode. ${ }^{1} \mathrm{H}$ NMR spectra were measured with a Bruker AVANCE $300 \mathrm{MHz}$ spectrometer. ${ }^{13} \mathrm{C}$ NMR spectra were measured with an Oxford NMR spectrometer. FT-IR spectra were recorded on a Nicolet 55XC spectrometer. UV-vis spectra were recorded on a Lambda 900 spectrophotometer in methanol.

\section{2. Synthesis of N'-(4- Dimethylaminobenzylidene)-4- dimethylaminobenzohydrazide (1)}

4-Dimethylaminobenzohydrazide $(1.0 \mathrm{mmol}, 0.18$ g) was added with stirring to 4-dimethylaminobenzaldehyde $(1.0 \mathrm{mmol}, 0.15 \mathrm{~g})$ in methanol. The mixture was heated under reflux for $1 \mathrm{~h}$, and cooled to room temperature. After filtration and slow evaporation at room temperature for a few days, colorless needle-shaped single crystals were formed. The crystals were collected by filtration, washed three times with methanol. Yield, $0.21 \mathrm{~g} \mathrm{(69}$ \%). Anal. Calcd. (\%) for $\mathrm{C}_{18} \mathrm{H}_{22} \mathrm{~N}_{4} \mathrm{O}: \mathrm{C}, 69.65 ; \mathrm{H}, 7.14 ; \mathrm{N}$, 18.05. Found (\%): C, 69.53; H, 7.27; N, 17.97. HRMS (ESI): $m / z$ calcd for $\mathrm{C}_{18} \mathrm{H}_{23} \mathrm{~N}_{4} \mathrm{O}[\mathrm{M}+\mathrm{H}]^{+} 311.1866$; found: 311.1869. Characteristic IR data $\left(\mathrm{KBr}, \mathrm{cm}^{-1}\right): 1608$ (s) $\left(v_{\mathrm{C}=\mathrm{N}}\right)$. UV-vis data in methanol $\left[\lambda_{\max }(\mathrm{nm}), \varepsilon\left(\mathrm{L} \mathrm{mol}^{-1}\right.\right.$ $\left.\mathrm{cm}^{-1}\right)$ ]: 230, 9360; 361, 25900. ${ }^{1} \mathrm{H}$ NMR (300 MHz, DMSO- $\left.d_{6}, \mathrm{ppm}\right): \delta 11.23(\mathrm{~s}, 1 \mathrm{H}), 8.28(\mathrm{~s}, 1 \mathrm{H}), 7.80(\mathrm{~d}, 2 \mathrm{H})$, $7.50(\mathrm{~d}, 2 \mathrm{H}), 6.75\left(\mathrm{dd}, J_{1}=9.0 \mathrm{~Hz}, J_{2}=7 \mathrm{~Hz}, 2 \mathrm{H}\right), 2.99(\mathrm{~s}$, $6 \mathrm{H}), 2.97$ (s, 6H). ${ }^{13} \mathrm{C}$ NMR (75 MHz, DMSO- $\left.d_{6}, \mathrm{ppm}\right): \delta$ $164.5,152.3,151.3,147.1,128.9,128.1,122.1,120.0,111.8$, $110.8,40.4,40.1,39.8,39.7,39.3,39.0$.

\section{3. Synthesis of N'-(2-Chloro- 5-nitrobenzylidene)-4- dimethylaminobenzohydrazide (2) and N'-(3-Methoxybenzylidene)-4- dimethylaminobenzohydrazide (3)}

Compounds $\mathbf{2}$ and $\mathbf{3}$ were synthesized by the same method as that described for 1, with 4-dimethylaminobenzaldehyde replaced by 2-chloro-5-nitrobenzaldehyde $(1.0 \mathrm{mmol}, 0.19 \mathrm{~g})$ for 2 and 3-methoxybenzaldehyde (1.0 $\mathrm{mmol}, 0.14 \mathrm{~g}$ ) for 3 . The filtrates for the two compounds were left still at room temperature to enable slow evaporation of the solvent to yield yellow block (for 2) and colorless needle (for 3) single crystals. For 2: Yield, $0.26 \mathrm{~g}$ (76 \%). Anal. Calcd. (\%) for $\mathrm{C}_{16} \mathrm{H}_{15} \mathrm{ClN}_{4} \mathrm{O}_{3}$ : C, 55.42; $\mathrm{H}$, 4.36; N, 16.16. Found (\%): C, 55.53; H, 4.28; N, 16.02 . HRMS (ESI): $m / z$ calcd for $\mathrm{C}_{16} \mathrm{H}_{15} \mathrm{ClN}_{4} \mathrm{O}_{3}$ [M] 347.0905; found: 347.0901 . Characteristic IR data $\left(\mathrm{KBr}, \mathrm{cm}^{-1}\right): 1610$ (s) $\left(v_{\mathrm{C}=\mathrm{N}}\right)$. UV-vis data in methanol $\left[\lambda_{\max }(\mathrm{nm}), \varepsilon\left(\mathrm{L} \mathrm{mol}^{-1}\right.\right.$ $\left.\mathrm{cm}^{-1}\right)$ ]: 280, 10500; 350, 12450. ${ }^{1} \mathrm{H}$ NMR $(300 \mathrm{MHz}, \mathrm{DM}-$ SO- $\left.d_{6}, \mathrm{ppm}\right): \delta 12.00(\mathrm{~s}, 1 \mathrm{H}), 8.85(\mathrm{~s}, 1 \mathrm{H}), 8.71(\mathrm{~d}, 1 \mathrm{H})$, $8.22\left(\mathrm{dd}, J_{1}=8.9 \mathrm{~Hz}, J_{2}=2.9 \mathrm{~Hz}, 1 \mathrm{H}\right), 7.84\left(\mathrm{dd}, J_{1}=8.9\right.$ $\left.\mathrm{Hz}, J_{2}=3.7 \mathrm{~Hz}, 3 \mathrm{H}\right), 6.78(\mathrm{~d}, 2 \mathrm{H}), 3.01(\mathrm{~s}, 6 \mathrm{H}) .{ }^{13} \mathrm{C} \mathrm{NMR}$ (75 MHz, DMSO- $\left.d_{6}, \mathrm{ppm}\right): \delta 163.7,153.2,145.8,141.2$, 138.3, 133.7, 131.6, 129.0, 127.9, 123.7, 121.5, 112.3, 40.7, 40.6. For 3: Yield, $0.237 \mathrm{~g}(80 \%)$. Anal. Calcd. (\%) for $\mathrm{C}_{17} \mathrm{H}_{19} \mathrm{~N}_{3} \mathrm{O}_{2}$ : C, 68.67; H, 6.44; N, 14.13. Found (\%): $\mathrm{C}, 68.54 ; \mathrm{H}, 6.57 ; \mathrm{N}, 14.24$. HRMS (ESI): $\mathrm{m} / z$ calcd for $\mathrm{C}_{17} \mathrm{H}_{20} \mathrm{~N}_{3} \mathrm{O}_{2}[\mathrm{M}+\mathrm{H}]^{+}$298.1207; found: 298.1213. Characteristic IR data $\left(\mathrm{KBr}, \mathrm{cm}^{-1}\right): 1616(\mathrm{~s})\left(v_{\mathrm{C}=\mathrm{N}}\right)$. UV-vis data in methanol $\left[\lambda_{\max }(\mathrm{nm}), \varepsilon\left(\mathrm{L} \mathrm{mol}^{-1} \mathrm{~cm}^{-1}\right)\right]: 275,5389$; $338,11300 .{ }^{1} \mathrm{H}$ NMR $\left(300 \mathrm{MHz}, \mathrm{DMSO}-d_{6}, \mathrm{ppm}\right): \delta 11.63$ $(\mathrm{s}, 1 \mathrm{H}), 8.39(\mathrm{~s}, 1 \mathrm{H}), 7.82(\mathrm{~d}, 2 \mathrm{H}), 7.37(\mathrm{t}, 1 \mathrm{H}), 7.24(\mathrm{~m}$, $2 \mathrm{H}), 7.00(\mathrm{~d}, 1 \mathrm{H}), 6.75(\mathrm{~d}, 2 \mathrm{H}), 3.81(\mathrm{~s}, 3 \mathrm{H}), 3.00(\mathrm{~s}, 6 \mathrm{H})$. ${ }^{13} \mathrm{C}$ NMR (75 MHz, DMSO- $\left.d_{6}, \mathrm{ppm}\right): \delta 162.6,159.1$, $152.5,147.3,137.6,131.4,128.7,123.6,120.0,114.9$, $112.2,110.8,54.5,40.6,40.5$.

\section{4. X-Ray Crystallography}

Single-crystal X-ray diffraction measurements for the compounds were carried out on a CrysAlis CCD diffractometer equipped with a graphite crystal monochromator for data collection at 298(2) K. The determinations of unit cell parameters and data collections were performed with Mo $K \alpha$ radiation $(\lambda=0.71073 \AA)$ and unit cell dimensions were obtained with least-squares refinements. Structures of the compounds were solved by direct methods using SHELXTL. ${ }^{5}$ Non-hydrogen atoms were located in successive difference Fourier syntheses. The final refinement was performed by full-matrix least-squares methods with anisotropic thermal parameters for non-hydrogen atoms on $F^{2}$. The hydrogen atoms were treated by a mixture of independent and constrained refinement. The amino $\mathrm{H}$ atoms in the compounds were located from difference Fourier maps and refined isotropically, with $\mathrm{N}-\mathrm{H}$ distances restrained to 0.90(1) $\AA$. The remaining hydrogen atoms were located at their calculated positions. The observed/unique ratio for compound $\mathbf{1}$ is low, which is due to the weak diffraction of the crystal determined. Crystallographic data and experimental details for structural analyses are summarized in Table 1.

\section{5. Antimicrobial Test}

The antibacterial activity of the compounds was tested against B. subtilis, E. coli, P. fluorescence and S. aureus using MH medium (Mueller-Hinton medium: casein hydrolysate $17.5 \mathrm{~g}$, soluble starch $1.5 \mathrm{~g}$, beef extract 1000 $\mathrm{mL}$ ), the antifungal activity of the compounds was tested against $A$. niger and $C$. albicans using RPMI-1640 medium (RPMI-1640 (GIBCO BRL) $10 \mathrm{~g}, \mathrm{NaHCO}_{3} 2.0 \mathrm{~g}, 0.165$ $\mathrm{mol} / \mathrm{L}$ morpholinepropanesulfonic acid (MOPS) (Sigma) $34.5 \mathrm{~g}$, triple distilled water $900 \mathrm{~mL}$, buffered to $\mathrm{pH} 7.0$ 
Table 1. Crystallographic data and refinement parameters for the compounds

\begin{tabular}{|c|c|c|c|}
\hline Compound & 1 & 2 & 3 \\
\hline Empirical formula & $\mathrm{C}_{18} \mathrm{H}_{22} \mathrm{~N}_{4} \mathrm{O}$ & $\mathrm{C}_{16} \mathrm{H}_{15} \mathrm{ClN}_{4} \mathrm{O}_{3}$ & $\mathrm{C}_{17} \mathrm{H}_{19} \mathrm{~N}_{3} \mathrm{O}_{2}$ \\
\hline Molecular weight & 310.4 & 346.8 & 297.4 \\
\hline Crystal color, habit & Colorless, needle & Yellow, block & Colorless, needle \\
\hline Crystal system & Orthorhombic & Monoclinic & Orthorhombic \\
\hline Space group & Pbca & $P c$ & $\mathrm{Pbca}$ \\
\hline \multicolumn{4}{|l|}{ Unit cell dimensions } \\
\hline$a(\AA)$ & $11.194(2)$ & $9.608(2)$ & $13.259(2)$ \\
\hline$b(\AA)$ & $8.029(1)$ & $14.631(2)$ & $8.389(1)$ \\
\hline$c(\AA)$ & $37.164(2)$ & $14.092(2)$ & $29.226(2)$ \\
\hline$\beta\left(^{\circ}\right)$ & 90 & $124.370(2)$ & 90 \\
\hline$V\left(\AA^{3}\right)$ & $3340.1(8)$ & $1635.1(5)$ & $3239.0(7)$ \\
\hline$Z$ & 8 & 4 & 8 \\
\hline$D_{\text {calc }}\left(\mathrm{g} \mathrm{cm}^{-3}\right)$ & 1.235 & 1.409 & 1.220 \\
\hline Absorption coefficient $\left(\mu, \mathrm{mm}^{-1}\right)$ & 0.079 & 0.256 & 0.082 \\
\hline Reflections collected/unique & $21612 / 2904$ & $11559 / 5689$ & $28475 / 2863$ \\
\hline Data/restraints/parameters & $2904 / 1 / 215$ & $5689 / 4 / 443$ & $2863 / 1 / 206$ \\
\hline Observed reflections $[I \geq 2 \sigma(I)]$ & 1084 & 3421 & 1239 \\
\hline$R_{1}, w R_{2}[I \geq 2 \sigma(I)]$ & $0.0698,0.1021$ & $0.0883,0.2226$ & $0.0861,0.1752$ \\
\hline$R_{1}, w R_{2}$ (all data) & $0.2534,0.1460$ & $0.1349,0.2752$ & $0.2126,0.2324$ \\
\hline Goodness of fit (GOF) on $F^{2}$ & 1.007 & 1.022 & 1.029 \\
\hline Largest differences in peak/hole $\left(\mathrm{e} / \AA^{3}\right)$ & 0.169 and -0.148 & 1.315 and -0.275 & 0.553 and -0.172 \\
\hline
\end{tabular}

with $1 \mathrm{~mol} / \mathrm{L} \mathrm{NaOH}\left(25^{\circ} \mathrm{C}\right)$, metered volume to $1000 \mathrm{~mL}$, filtered sterilization, conservation at $4{ }^{\circ} \mathrm{C}$ ). The MICs of the test compounds were determined by a colorimetric method using the dye MTT. ${ }^{6}$ A stock solution of the synthesized compound $(50 \mu \mathrm{g} / \mathrm{mL})$ in DMSO was prepared and graded quantities of the test compounds were incorporated in specified quantity of sterilized liquid medium (MH medium for antibacterial activity and RPMI-1640 medium for antifungal activity). A specified quantity of the medium containing the compound was poured into microtitration plates. Suspension of the microorganism was prepared to contain approximately $10^{5} \mathrm{cfu} / \mathrm{mL}$ and applied to microtitration plates with serially diluted compounds in DMSO to be tested and incubated at $37^{\circ} \mathrm{C}$ for $24 \mathrm{~h}$ and $48 \mathrm{~h}$ for bacterial and fungi, respectively. After the MICs were visually determined on each of the microtitration plates, $50 \mu \mathrm{L}$ of PBS (phosphate buffered saline 0.01 $\mathrm{mol} / \mathrm{L}, \mathrm{pH} 7.4, \mathrm{Na}_{2} \mathrm{HPO}_{4} \cdot 12 \mathrm{H}_{2} \mathrm{O} 2.9 \mathrm{~g}, \mathrm{KH}_{2} \mathrm{PO}_{4} 0.2 \mathrm{~g}$, $\mathrm{NaCl} 8.0 \mathrm{~g}, \mathrm{KCl} 0.2 \mathrm{~g}$, distilled water $1000 \mathrm{~mL}$ ) containing $2 \mathrm{mg}$ of $\mathrm{MTT} / \mathrm{mL}$ was added to each well. Incubation was continued at room temperature for 4-5 h. The content of each well was removed, and $100 \mu \mathrm{L}$ of isopropanol containing $5 \% 1 \mathrm{~mol} / \mathrm{L} \mathrm{HCl}$ was added to extract the dye. After $12 \mathrm{~h}$ of incubation at room temperature, the optical density (OD) was measured with a microplate reader at $550 \mathrm{~nm}$.

\section{Results and Discussion}

\section{1. Chemistry}

The synthesis of the compounds was carried out as outlined in Scheme 2. Single crystals of the compounds were obtained by slow evaporation of the methanolic solutions of the compounds.

\section{2. Structure Description of the Compounds}

The solid state structures of compounds 1, 2 and 3 determined by X-ray diffraction are shown in Figures 1, 2<smiles>[R]c1cc([R2])c(C=O)cc1[R]</smiles>

Scheme 2. The synthesis of the compounds. 1: $\mathrm{R}_{1}=\mathrm{R}_{3}=\mathrm{H}, \mathrm{R}_{2}=\mathrm{NMe}_{2} ; 2: \mathrm{R}_{1}=\mathrm{Cl}, \mathrm{R}_{2}=\mathrm{H}, \mathrm{R}_{3}=\mathrm{NO}_{2} ; 3: \mathrm{R}_{1}=\mathrm{R}_{2}=\mathrm{H}, \mathrm{R}_{3}=\mathrm{OMe}$. 
and 3, respectively. The hydrazone molecules in the compounds adopt $E$ configuration with respect to the $\mathrm{C}=\mathrm{N}$ double bonds. The distances between C9 and N1 [1.296(4) $\AA]$ in 1, C7 and N2 [1.269(8) $\AA]$ and C26 and N7 [1.256(8) $\AA]$ in 2 , and C8 and N1 [1.276(5) $\AA$ ] in 3, confirm them as typical double bonds. The distances between $\mathrm{C} 10$ and $\mathrm{N} 2$ [1.361(4) $\mathrm{A}]$ in 1, C8 and N3 [1.356(8) $\AA]$ and C25 and N6 [1.351(8) $\AA]$ in 2, and C9 and N2 [1.351(5) $\AA]$ in 3, are intermediate between single and double bonds, due to the conjugation effects of the molecules. The order of the distances of the $\mathrm{C}=\mathrm{N}$ bonds is $\mathbf{1}>\mathbf{3}>\mathbf{2}$, which is caused by the electron-donating or electron-withdrawing effects of the substituent groups. The remaining bond lengths in the three compounds are comparable to each other, and also similar to those in the literature. ${ }^{7}$ In the molecules of the three compounds, the dihedral angles between the two benzene rings are $10.9(5)^{\circ}$ for $1,5.7(4)^{\circ}$ and $2.5(4)^{\circ}$ for 2 , and $25.3(5)^{\circ}$ for 3 .

In the crystal structure of $\mathbf{1}$, molecules are linked through intermolecular $\mathrm{N}-\mathrm{H} \cdots \mathrm{O}$ and $\mathrm{C}-\mathrm{H} \ldots \mathrm{O}$ hydrogen bonds (Table 2), to form $1 \mathrm{D}$ chains along the $b$ axis (Figure 4). In the crystal structure of 2 , molecules are linked through intermolecular $\mathrm{N}-\mathrm{H} \ldots \mathrm{O}$ hydrogen bonds (Table 2), to form 1D chains along the $a$ axis (Figure 5). In the crystal structure of $\mathbf{3}$, molecules are linked through intermolecular $\mathrm{N}-\mathrm{H} \cdots \mathrm{O}$ and $\mathrm{C}-\mathrm{H} \cdots \mathrm{O}$ hydrogen bonds (Table 2), to form 1D chains along the $b$ axis (Figure 6).

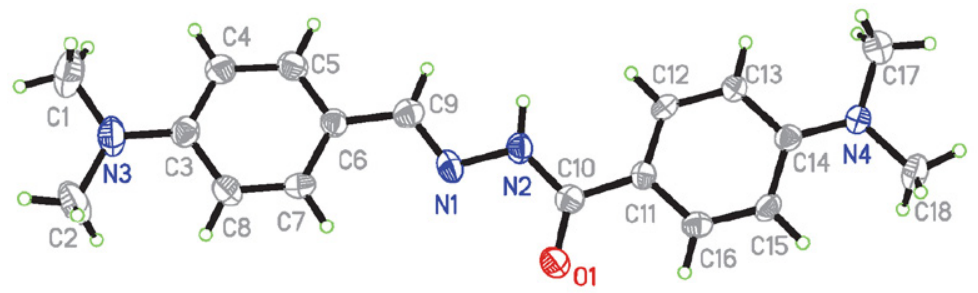

Figure 1 . The molecular structure of $\mathbf{1}$. The ellipsoids are shown with $30 \%$ probability.

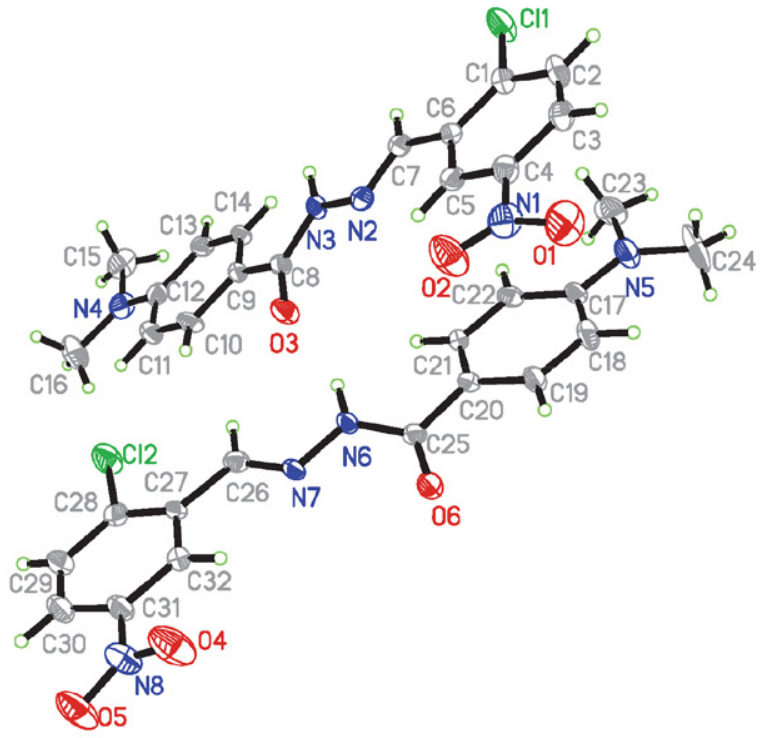

Figure 2. The asymmetric unit of $\mathbf{2}$. The ellipsoids are shown with $30 \%$ probability.

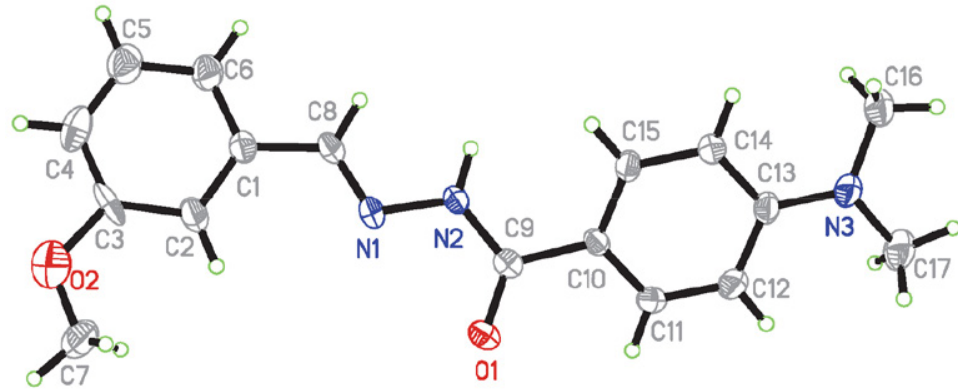

Figure 3. The molecular structure of 3 . The ellipsoids are shown with $30 \%$ probability. 


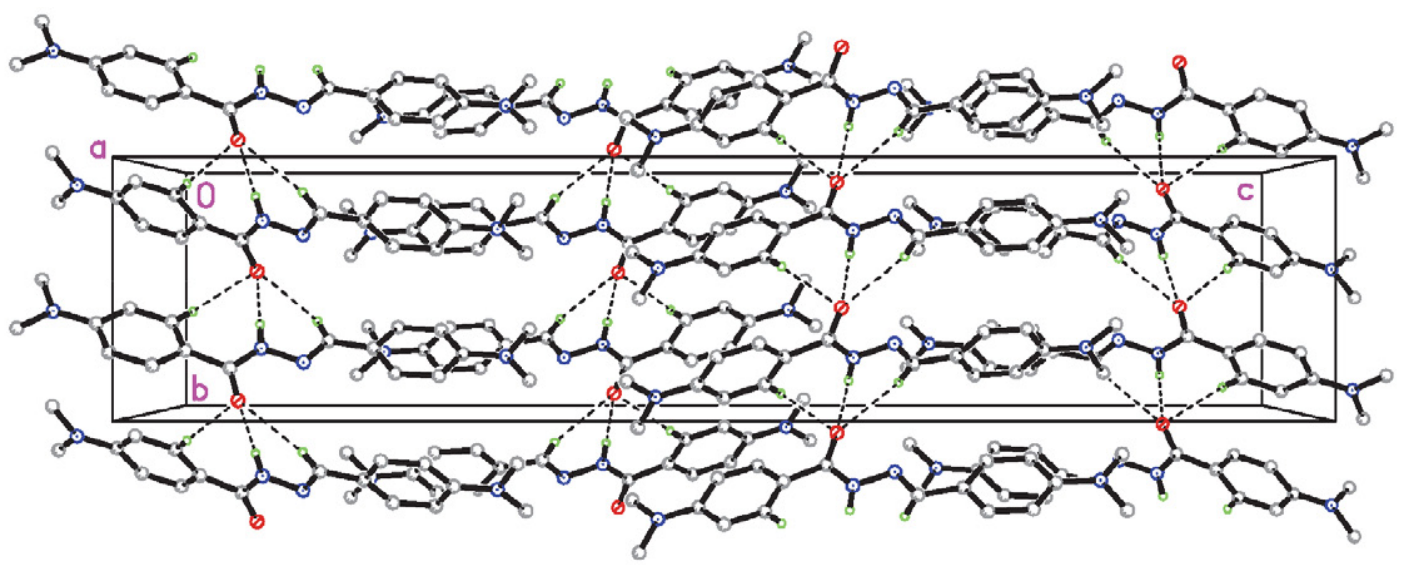

Figure 4. The packing diagram of $\mathbf{1}$. Hydrogen bonding interactions are shown as dashed lines.

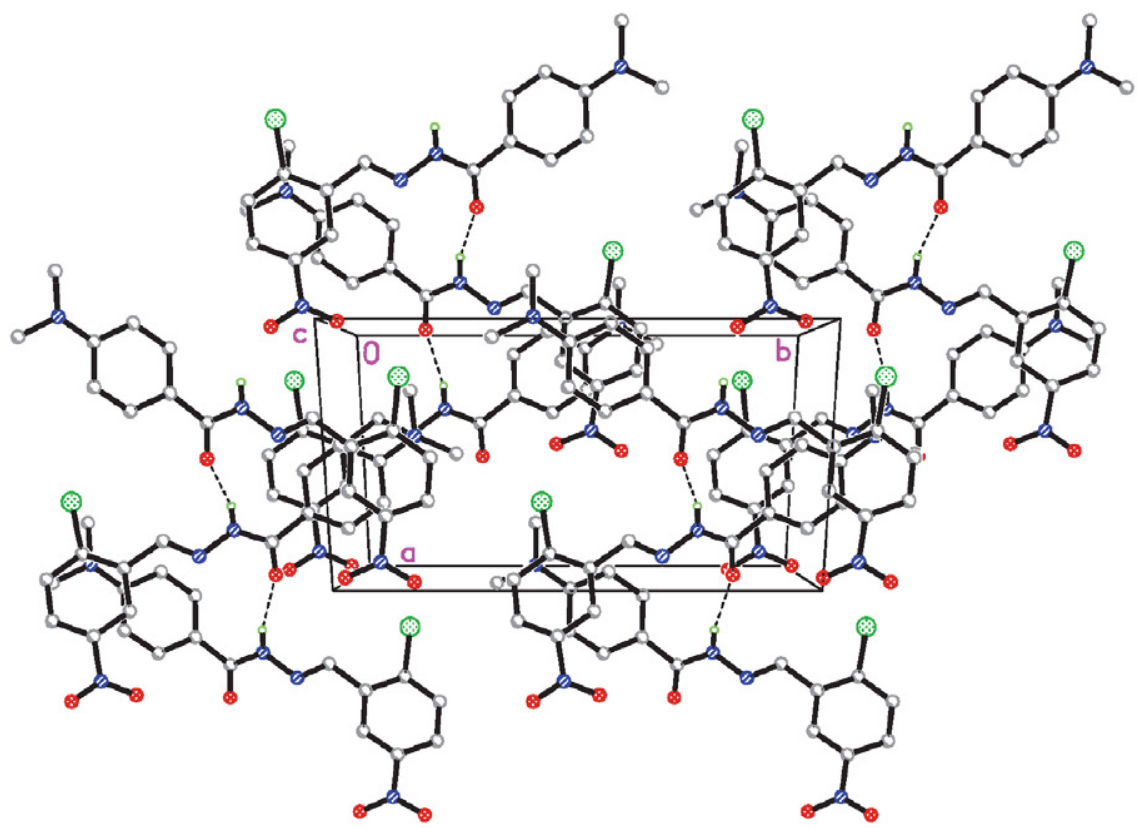

Figure 5. The packing diagram of $\mathbf{2}$. Hydrogen bonding interactions are shown as dashed lines.

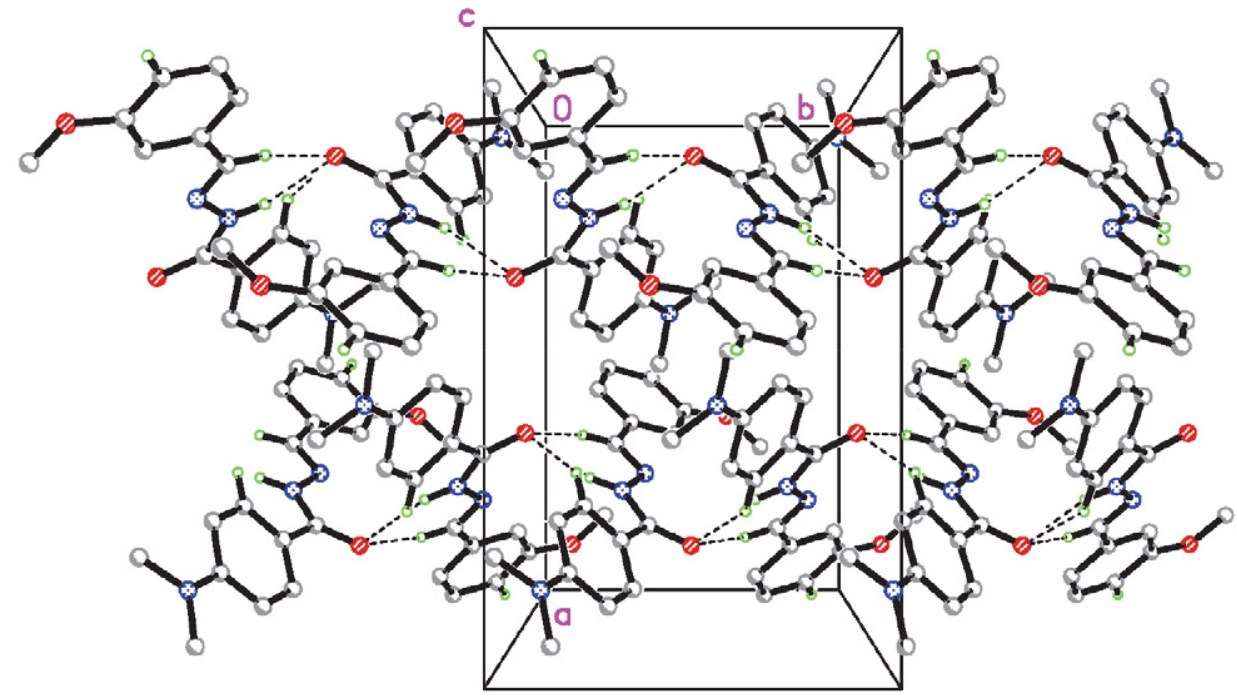

Figure 6. The packing diagram of $\mathbf{3}$. Hydrogen bonding interactions are shown as dashed lines. 
Table 2. Distances $(\AA)$ and angles $\left(^{\circ}\right)$ involving hydrogen bonding of the compounds

\begin{tabular}{|c|c|c|c|c|}
\hline D-H...A & $\mathbf{d}(D-H)$ & $d(H \cdots A)$ & $\mathrm{d}(D \cdots A)$ & $\operatorname{Angle}(D-\mathrm{H} \cdots A)$ \\
\hline \multicolumn{5}{|c|}{1} \\
\hline $\mathrm{N} 2-\mathrm{H} 2 \cdots \mathrm{O} 1^{\mathrm{i}}$ & $0.90(1)$ & $2.17(1)$ & $3.061(4)$ & $177(3)$ \\
\hline $\mathrm{C} 9-\mathrm{H} 9 \cdots \mathrm{O} 1^{\mathrm{i}}$ & 0.93 & $2.55(1)$ & $3.360(5)$ & $146(3)$ \\
\hline $\mathrm{C} 12-\mathrm{H} 12 \cdots \mathrm{O} 1^{\mathrm{i}}$ & 0.93 & $2.55(1)$ & $3.431(5)$ & $158(3)$ \\
\hline \multicolumn{5}{|c|}{2} \\
\hline N3-H3 $\cdots \mathrm{O}^{\mathrm{ii}}$ & $0.90(1)$ & $2.11(3)$ & $2.985(7)$ & $165(8)$ \\
\hline N6-H6‥O3 & $0.90(1)$ & $2.07(3)$ & $2.937(7)$ & $162(8)$ \\
\hline \multicolumn{5}{|c|}{3} \\
\hline $\mathrm{N} 2-\mathrm{H} 2 \cdots \mathrm{O} 1^{\mathrm{iii}}$ & $0.90(1)$ & $2.01(3)$ & $2.891(6)$ & $166(7)$ \\
\hline $\mathrm{C} 4-\mathrm{H} 4 \cdots \mathrm{O} 1^{\text {iv }}$ & 0.93 & $2.52(3)$ & $3.303(7)$ & $143(6)$ \\
\hline $\mathrm{C} 8-\mathrm{H} 8 \cdots \mathrm{O} 1^{\mathrm{iii}}$ & 0.93 & $2.49(3)$ & $3.298(7)$ & $145(6)$ \\
\hline $\mathrm{C} 15-\mathrm{H} 15 \ldots \mathrm{O} 1^{\mathrm{iii}}$ & 0.93 & $2.45(3)$ & $3.226(7)$ & $141(6)$ \\
\hline
\end{tabular}

\section{3. Infrared and UV-vis Spectra}

The sharp and medium stretching vibrations in the range $3200-3270 \mathrm{~cm}^{-1}$ in the spectra of the compounds indicate the presence of amino groups, $v_{\mathrm{N}-\mathrm{H}} \cdot{ }^{8} \mathrm{Com}-$ pounds 1, 2 and 3 exhibit strong stretching vibration frequencies of imino bonds formed by condensation of aldehyde and hydrazide at 1608,1610 and $1616 \mathrm{~cm}^{-1}$, respectively. ${ }^{9}$ The Ar-O stretching vibration frequencies of hydroxyl groups substituted on the benzene rings are observed in the range $1250-1270 \mathrm{~cm}^{-1}$ for the three compounds.

The compounds have two sets of bands in the UV region. The first centered at $230 \mathrm{~nm}$ for $\mathbf{1}, 280 \mathrm{~nm}$ for $\mathbf{2}$, and $275 \mathrm{~nm}$ for 3 , may be assigned to the $\pi \rightarrow \pi^{*}$ transitions. The second set centered at $360 \mathrm{~nm}$ for $1,350 \mathrm{~nm}$ for 2 , and $340 \mathrm{~nm}$ for $\mathbf{3}$, may be assigned to the $n \rightarrow \pi^{*}$ transitions.

\section{4. Antimicrobial Activities}

The MICs (minimum inhibitory concentrations) of the compounds against four bacteria strains are presented in Table 3. The activities of reference compounds kanamycin and penicillin were included. Compound 1 was found to be inactive against B. subtilis and P. fluorescence, and has strong activity against $E$. coli, and medium activity against $S$. aureus. Compound 2 was found to be active against all the bacteria, especially E. coli and S. aureus. Compound 3 was found to be inactive against $B$. subtilis, E. coli and $P$. fluorescence, and has weak activity against $S$. aureus. It is obvious that compound $\mathbf{2}$ showed stronger activities against the bacteria than compounds $\mathbf{1}$ and $\mathbf{3}$, which might be due to the presence of chloro and nitro substituent groups. It is notable that compound $\mathbf{2}$ has stronger activity against $E$. coli than the reference drug kanamycin. Chloro substituent is known as an important group for antibacterial activities. ${ }^{10}$ The results in this work are in accordance with those reported in the literature that the electron-withdrawing groups such as chloro and nitro can enhance the biological properties. ${ }^{4}$

The antifungal activity of the compounds was studied with two fungal strains by MTT method. The results are summarized in Table 3. Ketoconazole was used as the reference. The results indicate that the compounds have no activity against $A$. niger and $C$. albicans.

Table 3. MIC values of the compounds $(\mu \mathrm{g} / \mathrm{mL})$

\begin{tabular}{lcccccc}
\hline Compound & $\begin{array}{c}\text { Bacillus } \\
\text { subtilis }\end{array}$ & $\begin{array}{c}\text { Escherichia } \\
\text { coli }\end{array}$ & $\begin{array}{c}\text { Pseudomonas } \\
\text { fluorescence }\end{array}$ & $\begin{array}{c}\text { Staphylococcus } \\
\text { aureus }\end{array}$ & $\begin{array}{c}\text { Aspergillus } \\
\text { niger }\end{array}$ & $\begin{array}{c}\text { Candida } \\
\text { albicans }\end{array}$ \\
\hline $\mathbf{1}$ & $>50$ & 6.25 & $>50$ & 12.5 & $>50$ & $>50$ \\
$\mathbf{2}$ & 25 & 1.56 & 25 & 3.12 & $>50$ & $>50$ \\
$\mathbf{3}$ & $>50$ & $>50$ & $>50$ & $>50$ & $>50$ & 7.8 \\
Ketoconazole & $>50$ & $>50$ & 3.9 & 1 & $>50$ & $>50$ \\
Kanamycin & 0.39 & 3.9 & $>50$ & 2 & $>50$ & $>50$ \\
Penicillin & 0.78 & $>50$ & & & $>$ \\
\hline
\end{tabular}




\section{Conclusion}

Three new hydrazone compounds were synthesized and structurally characterized. Crystals of the compounds are stabilized by hydrogen bonds. The biological assay indicated that the presence of electron-withdrawing groups such as chloro and nitro can improve the antibacterial activities of the studied compounds. Among the three compounds, the one bearing chloro and nitro substituent dislayed the strongest activities against E. coli and S. aureus, therefore deserving further study to explore new antibacterial materials.

\section{Supplementary Material}

CCDC - 1035481 for $\mathbf{1}, 1035482$ for $\mathbf{2}$, and 1035483 for 3 contain the supplementary crystallographic data for this paper. These data can be obtained free of charge at http://www.ccdc.cam.ac.uk/const/retrieving.html or from the Cambridge Crystallographic Data Centre (CCDC), 12 Union Road, Cambridge CB2 1EZ, UK; fax: +44(0)1223336033 or e-mail: deposit@ccdc.cam.ac.uk.

\section{References}

1. (a) M. X. Song, B. Liu, S. W. Yu, S. H. He, Y. Q. Liang, S. F. Li, Q. Y. Chen, X. Q. Deng, Lett. Drug Des. Discov. 2020, 17, 502-511;

\section{DOI:10.2174/1570180816666190731113441}

(b) U. Debnath, S. Mukherjee, N. Joardar, S. P. S. Babu, K. Jana, A. K. Misra, Eur. J. Pharm. Sci. 2019, 134, 102-115; DOI:10.1016/j.ejps.2019.04.016

(c) E. M. Becker, D. B. Lovejoy, J. M. Greer, R. Watts, D. R. Richardson, British J. Pharm. 2003, 138, 819-830.

DOI:10.1038/sj.bjp.0705089

2. (a) R. Fekri, M. Salehi, A. Asadi, M. Kubicki, Inorg. Chim. Acta 2019, 484, 245-254; DOI:10.1016/j.ica.2018.09.022

(b) Y. C. Wu, X. D. Ding, L. Ding, Y. S. Zhang, L. Cui, L. Sun, W. Li, D. Wang, Y. F. Zhao, Eur. J. Med. Chem. 2018, 158, 247258; DOI:10.1016/j.ejmech.2018.09.004

(c) N. R. Appna, R. K. Nagiri, R. B. Korupolu, S. Kanugala, G. K. Chityal, G. Thipparapu, N. Banda, Med. Chem. Res. 2019, 28, 1509-1528; DOI:10.1007/s00044-019-02390-w

(d) K. Pyta, A. Janas, M. Szukowska, P. Pecyna, M. Jaworska, M. Gajecka, F. Bartl, P. Przybylski, Eur. J. Med. Chem. 2019, 167, 96-104; DOI:10.1016/j.ejmech.2019.02.009

(e) A. Erguc, M. D. Altintop, O. Atli, B. Sever, G. Iscan, G. Gormus, A. Ozdemir, Lett. Drug Des. Discov. 2018, 15, 193202; DOI:10.2174/1570180814666171003145227

(f) A. A. El-Tombary, S. A. M. El-Hawash, Med. Chem. 2014, 10, 521-532. DOI:10.2174/15734064113096660069

3. (a) Y.-L. Sang, X.-S. Lin, W.-D. Sun, Acta Chim. Slov. 2020, 67, 581-585; DOI:10.17344/acsi.2019.5595

(b) N. Biswas, S. Bera, N. Sepay, A. Pal, T. Halder, S. Ray,
S. Acharyya, A. K. Biswas, M. G. B. Drew, T. Ghosh, New J. Chem. 2020, 44, 3700-3716; DOI:10.1039/C9NJ06114B

(c) S. Dasgupta, S. Karim, S. Banerjee, M. Saha, K. D. Saha, D. Das, Dalton Trans. 2020, 49, 1232-1240;

DOI:10.1039/C9DT04636D

(d) A. A. Khandar, Z. M. Azar, M. Eskandani, C. B. Hubschle, S. Van Smaalen, B. Shaabani, Y. Omidi, Polyhedron 2019, 171, 237-248; DOI:10.1016/j.poly.2019.06.026

(e) L.-W. Xue, H.-J. Zhang, P.-P. Wang, Acta Chim. Slov. 2019, 66, 190-195;

(f) L.-W. Xue, Y.-J. Han, X.-Q. Luo, Acta Chim. Slov. 2019, 66, 622-628; DOI:10.17344/acsi.2019.5039

(g) C.-L. Zhang, X.-Y. Qiu, S.-J. Liu, Acta Chim. Slov. 2019, 66, 719-725; DOI:10.17344/acsi.2019.5241

(h) F.-M. Wang, L.-J. Li, G.-W. Zang, T.-T. Deng, Z.-L. You, Acta Chim. Slov. 2020, 67, 1155-1162;

DOI:10.17344/acsi.2020.6056

(i) Y. Tan, Acta Chim. Slov. 2020, 67, 1233-1238.

DOI:10.17344/acsi.2020.6136

4. M. Zhang, D.-M. Xian, H.-H. Li, J.-C. Zhang, Z.-L. You, Aust. J. Chem. 2012, 65, 343-350. DOI:10.1071/CH11424

5. G. M. Sheldrick, Acta Crystallogr. 2008, A64, 112-122. DOI:10.1107/S0108767307043930

6. J. Meletiadis, J. F. Meis, J. W. Mouton, J. P. Donnelly, P. E. Verweij, J. Clin. Microbiol. 2000, 38, 2949-2954.

DOI:10.1128/JCM.38.8.2949-2954.2000

7. (a) Y.-J. Wei, F.-W. Wang, J. Struct. Chem. 2011, 52, 755-759;

(b) Y.-M. Cui, Y.-J. Cai, W. Chen, J. Coord. Chem. 2011, 64, 1385-1392; DOI:10.1080/00958972.2011.571680

(c) Q.-Y. Zhu, Y.-J. Wei, F.-W. Wang, Polish J. Chem. 2009, 83, 1233-1240;

(d) H.-K. Fun, Z.-L. Lu, C.-Y. Duan, Y.-P. Tian, X.-Z. You, X.Y. Gong, Y.-M. Guo, Acta Crystallogr. 1997, C53, 1454-1455; DOI:10.1107/S0108270197008147

(e) S. S. S. Raj, H.-K. Fun, Z.-L. Lu, W. Xiao, X.-Y. Gong, C.M. Gen, Acta Crystallogr. 2000, C56, 1013-1014; DOI:10.1107/S010827010000799X

(f) D. Qu, F. Niu, X. Zhao, K.-X. Yan, Y.-T. Ye, J. Wang, M. Zhang, Z. You, Bioorg. Med. Chem. 2015, 23, 1944-1949; DOI:10.1016/j.bmc.2015.03.036

(g) M. Taha, N. Ismail, M. Baharudin, S. Yousuf, S. Siddiqui, K. Khan, S. Lalani, S. Mehboob, M. Choudhary, Med. Chem. Res. 2015, 24, 1310-1324. DOI:10.1007/s00044-014-1213-8

8. Y. G. Atovmyan, L. A. Nikonova, I. I. Chuev, A. N. Utenyshv, M. Z. Aldoshina, S. M. Aldoshin, J. Mol. Struct. 1999, 474, 167-175. DOI:10.1016/S0022-2860(98)00570-5

9. (a) S. N. Podyachev, I. A. Litvinov, R. R. Shagidullin, B. I. Buzykin, I. Bauer, D. V. Osyanina, L. V. Avvakumova, S. N. Sudakova, W. D. Habicher, A. I. Konovalov, Spectrochim. Acta A 2007, 66, 250-261; DOI:10.1016/j.saa.2006.02.049

(b) N. Galić, B. Perić, B. Kojić-Prodić, Z. Cimerman, J. Mol. Struct. 2001, 559, 187-194.

DOI:10.1016/S0022-2860(00)00703-1

10. (a) O. O. Güven, T. Erdogan, H. Goker, S. Yildiz, Bioorg. Med. Chem. Lett. 2007, 17, 2233-2236;

DOI:10.1016/j.bmcl.2007.01.061 
(b) Z.-Q. Sun, S.-F. Yu, X.-L. Xu, X.-Y. Qiu, S.-J. Liu, Acta Chim. Slov. 2020, 67, 1281-1289;

DOI:10.17344/acsi.2020.6236 (c) E.-C. Liu, W. Li, X.-S. Cheng, Acta Chim. Slov. 2019, 66, 971-977.

\section{Povzetek}

S pomočjo kondenzacije med 4-dimetilaminobenzohidrazidom kot prvim reaktantom in 4-dimetilaminobenzaldehidom, 2-kloro-5-nitrobenzaldehidom oz. 3-metoksibenzaldehidom kot drugim smo pripravili serijo treh novih hidrazonskih spojin. Spojine smo karakterizirali s pomočjo elementne analize, infrardeče in UV-vis spektroskopije, HRMS, ${ }^{1} \mathrm{H}$ NMR in ${ }^{13} \mathrm{C}$ NMR spektrov ter $\mathrm{z}$ rentgensko difrakcijsko analizo monokristalov. V kristalni strukturi so prisotne vodikove vezi. Spojinam smo s pomočjo MTT metode določili antibakterijsko delovanje (Bacillus subtilis, Escherichia coli, Pseudomonas fluorescence in Staphylococcus aureus) ter učinkovanje proti glivam (Aspergillus niger in Candida albicans). Rezultati kažejo, da je spojina 2 obetavno antibakterijsko sredstvo. 